\title{
An Empirical Study on Teaching Professionals' Work-Life Balance in Higher Learning Institutions with Special Reference to Namakkal District, Tamilnadu
}

\author{
K.G. Senthilkumar, Dr.S. Chandrakumaramangalam and Dr.L. Manivannan
}

\begin{abstract}
Many institutions of higher learning in India are swiftly integrating the advanced technology, mostly Information and Communication Technology (ICT) into their teaching learning process. This changing paradigm is putting heavy pressure on teaching professionals and leading imbalance in their family life. As a result, the work life balance (WLB) is indispensable for teaching professionals to cope with the uncertain environment of teaching learning process. To address this issue, this paper reviews work-life balance in general and aims at bringing out the relationship between the demographical variables such as age, gender and the level of stress in balancing work and personal life of teaching professionals. This paper also tries to bring out the satisfaction level of teaching professionals in balancing the work and personal life. The results of the chi-square test illustrate that there is a close relationship between the demographical variables taken for the research and the level of stress in balancing work and personal life. It is divulged from this analysis that majorities (90\%) of the respondents were not satisfied with their work life balance. In this fiercely competitive world, to be successful, it is momentous for any institutions to provide work-life balancing programs to their workforce to balance their work and personal life.
\end{abstract}

Keywords--- Information and Communication Technology (ICT), Work-Life Balance, Flexible Time in General, WorkLife Balancing Program

\section{INTRODUCTION}

$\mathrm{E}$ VEN though the work-life issues were dated back to 1960 's they have received greater concern during the past two decades. There has been a growing body of research in the field of work- life issues especially work-life balance as most

K.G. Senthilkumar, Associate Professor, Department of MBA, CMS College of Engineering, Namakkle, Tamilnadu, India. E-Mail: kgsenthil.mba@gmail.com

Dr.S. Chandrakumaramangalam, Associate Professor, School of Management Studies, Anna University of Technology, Coimbatore. Tamilnadu, India. E-Mail: ckmaucbe@gmail.com

Dr.L. Manivannan, Associate Professor, Department of Corporate Secretaryship, Erode Arts College, Erode, Tamilnadu, India. E-Mail: Im_erode@yahoo.co.in

DOI: 10.9756/BIJAIP.1389 of the organizations and employees seek ways to balance their work and family demands. Majority of these research and practices are aimed at developed regions of the world (Korabik et al 2003) [1] particularly concerned about the US and focused on the reconciliation of work and family. There is also a growing awareness of work- life issues in developing countries (Joplin et al. 2003) [2] According to Guest (2002) [3], the reasons for the rise of concern regarding work-life balance are the pressure and intensification of work, increasing focus on quality of home and community life and the attitudes and values of people. This in turn leads to significant rise in stress related to health problem, which in turn financially affect the both the employer as well as the government (Frone, Russell \& Cooper, 1997) [4]. Though, more researches are carried out, very minimum is concerned with teaching professionals. Hence, this paper aims at examining the teaching professionals stress level in balancing their work and family demands.

\section{A. Work-Life Balance: Definitions}

There is plethora of definitions to work-life balance. It means different things to different people at different times. The phrase work-life balance was called as an 'almost taken for granted metaphor' by Pitt-Catsouphes, et al. (2006) [5]. Generally, work-life balance is defined as a state of equilibrium in which the demands of both a person's job and personal life are equal. It is nothing but investing equal amounts of time and energy between work and personal life. Parkes and Langford (2008) [6] defined work-life balance as 'an individual's ability to meet their work and family commitments, as well as other non-work responsibilities and activities. Kirchmeyer (2000) [7] simply defined work-life balance as 'achieving satisfying experiences in all life domains'. Lewis (2000) [8] differently conceptualized worklife balance as a two way process involving a consideration of the needs of employees as well as those of employers. Clark (2000) [9], while defining work-life balance introduced satisfaction and role conflict. He defined it as satisfaction and good functioning at work and at home, with minimum of role conflict. Greenblatt (2002) [10] viewed work-life balance as "the absence of unacceptable levels of conflict between work and non-work demands.

Whereas the traditional definitions focussed on the absence of conflict between the paid work and personal life sphere the new school of thought proposed different characteristics to 
work-life balance. Greenhaus et al., (2003) [11] defined worklife balance as the extent to which individuals are equally engaged in and equally satisfied with work and family roles. They projected equality and engagement to define balance. Another new school of thought by Grzywacz and Carlson (2007) [12] viewed work-life balance as "accomplishments of role related expectations that are negotiated and shared between an individual and his/her role related partners in the work and family domains”.

\section{B. Need for Work-Life Balance in India}

As being a developing economy, Indian workforce is facing fierce competition. Due to the liberalization, privatisation and globalization, the workforce of India are always under pressure. Apart from this, the advent of Information and Communication Technology (ICT), and the increased level of female participation in the workforce add complexity while balancing paid work and personal life. Hence, it is crucial that the workforce of India have to be given work-life balancing programs to balance their paid work and their personal life.

\section{Significance of Work-Life Balance for the Indian Teaching Professionals}

There are certain reasons for the inevitability of work-life balance to the teaching professionals. First amongst them is the tremendous advancement in technology particularly the development of ICT which has transformed the nature of delivery systems in higher education. ICT has transformed the teaching learning process from conventional, which is teacher centric, to constructivist learning, which is learner centric. In the new learning environment the teacher has to cope with many more uncertainties which lead to stress and leading imbalance in their family life. Hence, work-life balance is indispensable for teaching professionals.

Another important reason has been the role played by the teaching professionals. In this contemporary world, the teaching professionals play assortment of roles; such as pedagogical, managerial, technical and subject-designing role (Bennet \& Lockyer, 2004) [13]. These multiple roles of teaching professionals constantly keep them under pressure and lead to imbalance in their work and personal life.

Hence, this study is focused on teaching professionals with the objectives of finding the relationship between the demographical variables (such as marital status and partner employment status) and the level of stress in balancing work and life.

Based on the above objectives the following hypotheses have been formed.

1. There is a relationship between age of the respondents and their level of stress in balancing paid work and personal life.

2. There is a relationship between gender of the respondents and their level of stress in balancing paid work and personal life.

\section{RESEARCh DESIGN}

The study was undertaken in the Namakkal District of Tamilnadu, India. The respondents were the faculty members working in self financing Engineering Colleges in the Namakkal District and selected using stratified Random Sampling method. The study was aimed at unearthing the relationship between demographical factors and the level of stress in balancing work and personal life among the sample respondents. For this purpose the level of stress was selected as the dependent variable. The independent variables such as marital status and partner employment status were chosen for this analysis.

The questionnaire was sent to the 240 faculty members but only 197 responses were received and the response rate of $82.08 \%$. Hence, the total numbers of respondents were 197, including 101 male respondents and 96 female respondents. Among the 197 respondents 83 were and 114 were unmarried and 64 respondents from married category reported that they have an employed partner.

\section{DATA ANALYSIS}

The data thus collected were sub divided into suitable tables and statistical tools like percentage, average, range, S.D, two-way tables and chi-square test were employed appropriately. Henry Garret ranking technique was employed to find the expectations by the staff members.

\section{A. Age and Level of Stress}

For the purpose of the study age of the respondent has been classified into 3 categories viz., young age (below 30 years), middle age (30-50 years) and old age (Above 51 years). The sample consists of 54 (32\%) respondents belonging to young age category, 109 (55.3\%) respondents belonging to middle age category and $34(17.3 \%)$ respondents belonging to old age category. The distribution of sample respondents according to age and their level of stress in balancing work and life are shown in Table 1.

Table 1: Age and Level of Stress

\begin{tabular}{|c|c|c|c|c|c|c|}
\hline & \multirow{2}{*}{ No. of } & & \multicolumn{3}{|c|}{ Level of Stress } & \multirow{2}{*}{ Ag } \\
\cline { 4 - 6 } & $\begin{array}{c}\text { Respon- } \\
\text { dents }\end{array}$ & $\%$ & $\begin{array}{c}\text { Ave- } \\
\text { rage }\end{array}$ & $\begin{array}{c}\text { Mi } \\
\mathrm{n}\end{array}$ & Max & \\
\hline $\begin{array}{c}\text { Young age } \\
\text { (Below 30 } \\
\text { years.) }\end{array}$ & 54 & 27.4 & 37.0 & 33 & 41 & 1.7 \\
\hline $\begin{array}{c}\text { Middle age } \\
\text { (30-50 years.) }\end{array}$ & 109 & 55.3 & 37.7 & 34 & 40 & 1.7 \\
\hline $\begin{array}{c}\text { Old age } \\
\text { (Above 51 } \\
\text { years.) }\end{array}$ & 34 & 17.3 & 38.6 & 35 & 42 & 1.5 \\
\hline Total & 197 & 100. & & & & \\
\hline
\end{tabular}

It could be observed from the Table 1 that the level of stress perceived by the young age category of respondents ranged between 33 and 41 with an average of 37.0. The level of stress perceived by middle age category of respondents ranged between 34 and 40 with an average of 37.7. On the other hand, the level of stress perceived by the respondents of 
old age category ranged between 35 and 42 with an average of 38.6. From the analysis it is concluded that the respondents of old age category have perceived maximum level of stress.

\section{B. Age and Level of Stress (Two-Way Table)}

With the view to find the degree of association between age of the respondents and their level of stress in balancing work and personal life, a two-way table has been prepared and depicted in Table 2.

Table 2: Age and Level of Stress (Two-Way Table)

\begin{tabular}{|c|c|c|c|c|}
\hline \multirow{2}{*}{ Age } & \multicolumn{3}{|c|}{ Level of Stress } & \multirow{2}{*}{ Total } \\
\cline { 2 - 4 } & Low & Medium & High & \\
\hline $\begin{array}{c}\text { Young age } \\
\text { (Below 30 } \\
\text { years.) }\end{array}$ & $\begin{array}{c}12 \\
(22.2 \%)\end{array}$ & $\begin{array}{c}21 \\
(38.9 \%)\end{array}$ & $\begin{array}{c}21 \\
(38.9 \%)\end{array}$ & 54 \\
\hline $\begin{array}{c}\text { Middle age } \\
\text { (30-50 years.) }\end{array}$ & $\begin{array}{c}17 \\
(15.6 \%)\end{array}$ & $\begin{array}{c}68( \\
62.4 \%)\end{array}$ & $\begin{array}{c}24 \\
(22.0 \%)\end{array}$ & 109 \\
\hline $\begin{array}{c}\text { Old age ( } \\
\text { Above 51 } \\
\text { years.) }\end{array}$ & $\begin{array}{c}10 \\
(29.4 \%)\end{array}$ & $\begin{array}{c}10 \\
(29.4 \%)\end{array}$ & $\begin{array}{c}14(1.2 \%) \\
40\end{array}$ & 34 \\
\hline Total & 39 & 99 & 59 & 197 \\
\hline
\end{tabular}

It is highlighted in Table 2 that the percentage of high level of stress perceived in balancing work and life was the highest (41.2\%) among the respondents of old age category and the same was the lowest (22\%) among the middle age category of respondents. The percentage of medium level of stress was highest (62.4\%) among the middle age category of respondents and the same was the lowest (29.4\%) among old age category of respondents. On the other hand, the percentage of low level of stress was the highest (29.4\%) among old age category of respondents and same was the lowest (15.6\%) among middle age category.

\section{Age and Level of Stress (Chi-Square Test)}

In order to find the relationship between the age of the respondent and their level of stress in balancing work and life, chi-square test has been used and the result is shown in the Table 3.

Table 3: Age and Level of Stress (Chi-Square Test)

\begin{tabular}{|c|c|c|c|c|}
\hline Factors & $\begin{array}{c}\text { Calculated } \\
\chi^{2} \text { Value }\end{array}$ & $\begin{array}{c}\text { Table } \\
\text { Value }\end{array}$ & D.F & Remarks \\
\hline Age & 15.400 & 9.488 & 4 & $\begin{array}{c}\text { Significant } \\
\text { at 5\% } \\
\text { Level }\end{array}$ \\
\hline
\end{tabular}

It is identified from the Table 3 that the calculated chisquare value is greater than the table value and result is significant at $5 \%$ level. Hence the hypothesis "Age of the respondents and their level of stress in balancing work and life" are associated holds good. From the analysis it is concluded that there is a close relationship between age of the respondents and their level of stress in balancing work and life.

\section{Gender and Level of Stress}

For the purpose of the study gender of the respondents has been studied under two category viz., male and female. The sample consists 101 (51.3\%) respondents of male category and the remaining 96 (48.7\%) belonging to female category. The distribution of sample respondents according to gender and level of stress in balancing work and life is shown in the Table 4.

Table 4: Gender and Level of Stress

\begin{tabular}{|c|c|c|c|c|c|c|}
\hline \multirow{3}{*}{ Sex } & \multirow{3}{*}{$\begin{array}{l}\text { No. of } \\
\text { Respo- } \\
\text { ndents }\end{array}$} & \multirow{3}{*}{$\%$} & \multicolumn{3}{|c|}{ Level of Stress } & \multirow{3}{*}{ S.D } \\
\hline & & & \multirow{2}{*}{$\begin{array}{l}\text { Ave- } \\
\text { rage }\end{array}$} & \multicolumn{2}{|c|}{ Range } & \\
\hline & & & & Min & Max & \\
\hline Male & 101 & 51.3 & 37.0 & 34 & 41 & 1.9 \\
\hline $\begin{array}{c}\text { Fema } \\
\text { le }\end{array}$ & 96 & 48.7 & 38.1 & 33 & 42 & 1.5 \\
\hline Total & 197 & 100.0 & & & & \\
\hline
\end{tabular}

It could be seen from the Table 4 that the level of stress perceived by the male respondents ranged between 34 and 41 with an average of $37.0 \%$ similarly the female respondents express their level of stress ranged between 33 and 42 with an average of 38.1. From the analysis it is concluded that the female respondents have perceived maximum level of stress.

With the view to find the degree of association between gender of the respondents and their level of stress, a two-way table has been prepared and is depicted in Table 5.

Table 5: Gender and Level of Stress (Two-Way Table)

\begin{tabular}{|c|c|c|c|c|}
\hline \multirow{2}{*}{ Gender } & \multicolumn{3}{|c|}{ Level of stress } & \multirow{2}{*}{ Total } \\
\cline { 2 - 4 } & Low & Medium & High & \\
\hline Male & $16(15.9 \%)$ & $\begin{array}{c}38 \\
(37.6 \%)\end{array}$ & $47(46.5 \%)$ & 101 \\
\hline Female & $12(12.5 \%)$ & $\begin{array}{c}23 \\
(24.0 \%)\end{array}$ & $61(63.5 \%)$ & 96 \\
\hline Total & 39 & 99 & 59 & 197 \\
\hline
\end{tabular}

It is highlighted from Table 5 that the percentage of high level of stress perceived is the highest (63.5\%) among the female respondents and the same is the lowest (46.5\%) among the male respondents. The percentage of medium level of stress is the highest (37.6\%) among the male category of respondents and the same is the lowest (24.0\%) among female category of respondents. On the other hand, the percentage of low level of stress is the highest (15.9\%) among male category of respondents and the same is lowest (12.5\%) among the female category of respondents.

In order to find the relationship between the gender of the respondents and their level of stress in balancing work and life, chi-square test has been used and the result of the test is shown in Table 6.

Table 6: Gender and Level of Stress (Chi-Square Test)

\begin{tabular}{|c|c|c|c|c|}
\hline Factors & $\begin{array}{c}\text { Calculated } \\
\chi^{2} \text { Value }\end{array}$ & $\begin{array}{c}\text { Table } \\
\text { Value }\end{array}$ & D.F & Remarks \\
\hline Gender & 27.253 & 5.991 & 2 & $\begin{array}{c}\text { Significant at } \\
5 \% \text { Level }\end{array}$ \\
\hline
\end{tabular}

It is highlighted from the Table 6 that the calculated chisquare value is greater than the table value and result is significant at 5\% level. Hence the hypothesis "Gender of the respondents and their level of stress in balancing work and life" are associated holds good. From the analysis, it is 
concluded that there is a close relationship between Gender of the respondents and their level of stress in balancing work and life.

\section{Discussion}

It is revealed from the analysis that the respondents of old age category and female category have perceived maximum level of stress in balancing their work and life. The results of the chi-square showed that there is a close relationship between age of the respondents and their level of stress in balancing work and their personal life. Similarly, there is a close relationship between gender of the respondents and their level of stress in balancing work and life. Hence, it is suggested that the institutions should develop work life policies such as special leave facilities, parental or family support programs and health care programs.

It is divulged from this analysis that majority (90\%) of the respondents were not satisfied with their work-life balance due to their work load i.e., evening coaching classes/weekend special classes for slow learners and the administrative work done by them. This left them frustrated as they were not able to spend quality time with their family. This finding is similar with the research findings of Pocock et al (2007) [14]. They explained that longer work hours worked is consistently associated with worse work-life outcomes. It is divulged from the analysis that majority of the respondents (93\%) agreed that work-life balance is a joint responsibility of both employees and employers.

\section{CONCLUSION}

In this contemporary world, the role of teaching professionals are ever changing and evolving and the new teaching learning environment puts heavy pressure on teaching professionals. This work pressure will have an impact on their personal life and lead to imbalance in their work and life. Hence, teaching professionals' work life balance is the most significant aspect in the success and development of educational institutions. It is vital for any institution to provide facilities to their staff members to get relieved from stress for balancing their work and personal life. The further research may determine the suitable work-life balancing programs for teaching faculty members in higher learning institutions in India. It is a rewarding exercise to the researchers and helps to gain knowledge on socially relevant problems.

\section{REFERENCES}

[1] K. Korabik, D.S. Lero, and R. Ayman, "A multi-level approach to cross cultural work-family research”, International Journal of Cross Cultural Management, Vol. 3, No. 3, Pp. 289-303, 2003.

[2] J.R.W. Joplin, M.A. Shaffer, A.M. Francesco, and T. Law, "The macro environment and work-family conflict: Development of a cross- cultural comparative frame work", International Journal of Cross Cultural Management, Vol. 3, No. 3, Pp. 305-328, 2003.

[3] D.E. Guest, "Perspectives on the study of work-life balance", Social Science Information, Vol. 41, No. 2, Pp.255-279, 2002.

[4] M. Frone,, M. Russell, and Cooper, "Relation of work-family conflict to health outcomes: a four year longitudinal study of employed parents", Journal of Occupational and Organizational Psychology. Vol. 70, No. 4, Pp. 325-335, 1997.
[5] M. Pitt-Catsouphes, E.E. Kossek, and S. Sweet, "Charting new territory: Advancing multi-disciplinary perspectives, methods, and approaches in the study of work and family”. (PDF) Pp. 1-16, 2006.

[6] LP Parkes and PH Langford, "work-life balance or work-life alignment? A test of the importance of work-life balance for employee engagement and intention to stay in organization" Journal of Management and Organization, Vol. 14, No.3, Pp. 267-284, 2008.

[7] C. Kirchmeyer, "Work-life initiatives: Greed or benevolence in regarding workers' time?” In: C.L. Cooper and D M Rousseau (Eds), Trends in Organizational Behaviour, Vol. 7, Pp. 79-97, 2000.

[8] S. Lewis, "Workplace programmes and policies in the United Kingdom”, in Hass I., H Wans P. and G.Russell (eds), Organizational change and Gender Equity, London. Sage, 2000.

[9] S.C. Clark, "Work/family border theory: A new theory of work/family balance”, Human Relations, Vol. 53, No. 6, Pp747-770, 2000.

[10] E. Greenblatt, "work -life balance: Wisdom or Whining”, Organizational Dynamics, Vol. 31, No. 2, Pp.177-193, 2002

[11] J.H Greenhaus, K.M. Collins, and J.D. Shaw, "The relation between work-family balance and quality of life", Journal of Vocational Behaviour, Vol. 63, Pp.510-531, 2003.

[12] J.G. Grzywacz, and D.S.Carlson, "Conceptualizing work-family balance: Implications for practice and research”, Advances in Developing Human Resources, Vol. 9, No. 4, Pp.455-471, 2007.

[13] S. Bennet, and L. Lockyer, "Becoming an online teacher: Adapting to a changed environment for teaching and learning in higher education”, Educational Media International, Vol. 41, No.3, Pp. 231-244, 2004.

[14] B. Pocock, N. Skinner, and P. Williams, "Work, Life and Time; The Australian work and life Index", Centre for work and life, Hawke Research Institute: University of South Australia, 2007.

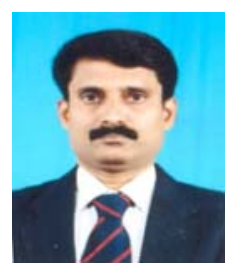

K.G. Senthilkumar was born on 29th June 1971 at Erode, Tamilnadu, India. He has completed M.Phil (Management) in the year 2007, MBA in the year 1995 and B.Sc. (Biochemistry) in the year 1992 from Bharathiar University, Coimbatore, and Tamilnadu, India. Currently he is pursuing $\mathrm{PhD}$ in Management from Anna University of Technology, Coimbatore. He has 9 years of experience in the industry and 8 Years of experience in teaching profession. He is having profound interest in Human Resource Management and currently working as Associate Professor, Department of Management Studies in CMS College of Engineering, Namakkal, Tamilnadu, India. 